\title{
Effects of Bamboo Charcoal Added Feed on Reduction of Ammonia and Growth of Pangasius hypophthalmus
}

\author{
Quaiyum MA, Jahan R, Jahan N, Akhter T and Islam M Sadiqul* \\ Department of Fisheries Biology \& Genetics, Bangladesh Agricultural University, Mymensingh-2202, Bangladesh
}

\begin{abstract}
A 50-day feeding trial was conducted to determine the effects of dietary bamboo charcoal (BC) on ammonia $\left(\mathrm{NH}_{3}-\mathrm{N}\right)$ excretion and growth performances of Pangasius hypophthalmus. Four levels of $\mathrm{BC}(0 \%, 0.5 \%, 1 \%$ and $2 \%)$ were supplemented to the diet composition and fed to fish (initial body weight $1.18 \pm 0.04 \mathrm{~g}$ ) twice a day. At the end of the trial, mean of final weight $(\mathrm{g})$, final length $(\mathrm{cm})$, weight gain $(\mathrm{g})$, length gain $(\mathrm{cm})$, percent weight gain, percent length gain, specific growth rate (\% per day), feed conversion ratio, survival rates and water quality parameters i.e, ammonia $\left(\mathrm{NH}_{3}-\mathrm{N}\right), \mathrm{pH}$, and dissolved oxygen were measured and found that fish fed $2 \%$ BC diet showed significantly $(P<0.05)$ higher growth enhancement than those of fish fed the control diet $(0 \% \mathrm{BC})$. Ammonia concentration over the experimental period decreased with increasing dietary BC. Moreover, in histological observation it was found that the villus height and villus area in all intestinal segments tended to increase with increasing dietary BC supplementation. The present results indicate stimulating effects of dietary $\mathrm{BC}$ on intestinal villi and the diet supplemented with $2 \% \mathrm{BC}$ was found to have a suitable level to fulfill the maximum growth performances of $P$. hypophthalmus and to decrease the ammonia concentration.
\end{abstract}

Keywords: Bamboo charcoal; Ammonia; Growth; Pangasius hypophthalmus

\section{Introduction}

There is a great potential for Pangasius hypophthalmus in Bangladesh. It is very much demandable in local markets because of its lower market price. The vast majority of poor people consume $P$. hypophthalmus as this fish is delicious and tasty due to its high fat content. Moreover, the climate, water and soil conditions of Bangladesh have proved totally suitable for $P$. hypophthalmus production and it is one of the most suitable catfishes for rearing in ponds [1]. Pangasius culture has proved itself as a profitable enterprise due to year round production, quick growth and high productivity. In addition, it can be stocked at a much higher density in ponds compared to other cultivable species [2].

However, costly feed and low market price has slowed progress in farming of this fish. In addition, due to high accumulation of nitrogenous waste products that is toxic to fish considered as a limiting factor for growth and survival of fish are affecting the culture of this species [3]. One of the sources of this nitrogenous waste (e.g. ammonia) is from the supplemented feed that fed to fish. An effective way to reduce the waste load is to modify aqua feeds with the aim of reducing excretion of nitrogen, phosphorus and total solids relative to fish growth [4,5]. Therefore, several efforts have been made to produce high quality animal products without using medicines and to reduce environmental contamination by efficient utilization of natural substances. Some of these natural substances (e.g. wood charcoal, bamboo charcoal, coconut shell charcoal etc.) are not cited in the scientific literature, but are used locally. Like wood charcoal bamboo charcoal (BC) is also an activated charcoal made by dry distillation of a thick-stemmed bamboo and powder of which is known as a universal adsorbent, because it can bind with variety molecules since it contains a complex network of pores of various shapes and sizes [6]. Now-a-days, BC has been used in animal feed formulation as an additive because they absorb ammonia and nitrogen, and activates the intestinal function through eliminating the poisons and impurities from the gastrointestinal tract of land animals $[7,8]$. Utilization of charcoal from wood or bamboo may provide an economical way to eliminate noxious substances because of their cheaper cost [9]. Moreover, BC is considered to have a higher adsorption capacity than wood charcoal because it has about 4 times more cavities, 3 times more mineral content and 4 times better absorption rate [6]. Reports have clarified the ammonia adsorption effect of BC in aqueous solution [10], and dietary addition of BC effects on digestion, nitrogen retention and excretion of growing goats [8]. They also found that goats fed a diet containing $0.5 \mathrm{~g}$ of BC per $\mathrm{kg}$ of body weight grew faster than the controls. Recently it was found that bamboo charcoal boosts tilapia growth [11]. However, very limited studies about $\mathrm{BC}$ in aquatic animal nutrition as a feed ingredient have been conducted.

Therefore, the major purpose in the present study was to assess the effectiveness of dietary BC supplementation on growth performance of $P$. hypophthalmus and elimination of ammonia nitrogen excretion from the water during study period.

\section{Materials and Methods}

\section{Experimental site}

The experiment was carried out in the Backyard Laboratory of the Faculty of Fisheries, Bangladesh Agricultural University, Mymensingh, Bangladesh. The experiment was conducted for a period of 50 days. The research work was undertaken in 13 glass aquaria (average capacity 50L). An adequate level of dissolved oxygen in each aquarium was maintained through artificial aeration during the experimental period.

*Corresponding author: M Sadiqul Islam, Department of Fisheries Biology and Genetics, Faculty of Fisheries, Bangladesh Agricultural University, Mymensingh-2202, Bangladesh, E-mail: sadiqul1973@yahoo.com

Received August 18, 2014; Accepted September 22, 2014; Published October 02, 2014

Citation: Quaiyum MA, Jahan R, Jahan N, Akhter T, Sadiqul IM (2014) Effects of Bamboo Charcoal Added Feed on Reduction of Ammonia and Growth of Pangasius hypophthalmus. J Aquac Res Development 5: 269. doi:10.4172/2155 9546.1000269

Copyright: (c) 2014 Quaiyum MA, et al. This is an open-access article distributed under the terms of the Creative Commons Attribution License, which permits unrestricted use, distribution, and reproduction in any medium, provided the original author and source are credited. 
Citation: Quaiyum MA, Jahan R, Jahan N, Akhter T, Sadiqul IM (2014) Effects of Bamboo Charcoal Added Feed on Reduction of Ammonia and Growth of Pangasius hypophthalmus. J Aquac Res Development 5: 269. doi:10.4172/2155-9546.1000269

Page 2 of 5

\section{Preparation of $\mathrm{BC}$}

Bamboo was cut into small pieces and put into a tightly sealed container made of iron. This is then placed on a hot fire for at least an hour. Once the fire was out, the container left to cool down completely before it opened. The $\mathrm{BC}$ then pounded into a fine powder and the composition of $\mathrm{BC}$ is as follows in Table 1.

\section{Feed formulation}

Standard fish feed (Table 2) obtained from commercial feed company (Mega Feed Co. Ltd., Bangladesh) was used as a basal feed supplemented with $\mathrm{BC}$ powder at $0,0.5,1.0$ and $2 \%$ in control, $\mathrm{T}_{1}, \mathrm{~T}_{2}$ and $\mathrm{T}_{3}$, respectively. Diets were prepared by mixing the dry ingredients and water (35\% of the dry weight of ingredients) and then pellet-type diets were produced through a meat grinder with a diameter disc (size, $1.9-2.2 \mathrm{~mm})$. The diets were later oven dried $\left(60^{\circ} \mathrm{C}\right.$ for $\left.2 \mathrm{~h}\right)$ to approximately $11 \%$ moisture. After preparation, the diets were stored at refrigerator until used.

Fingerling collection and stocking of fish: Fingerling of $P$. hypophthalmus was collected from the local fish seed retailer and carefully transported to avoid physical injury. One fish per liter stocking density and three aquaria were used for each treatment.

Feeding rates: Fingerlings were fed with experimental diets twice a day in the morning at 9.00 am and in the afternoon at $3.00 \mathrm{pm}$ throughout the study period. Fingerling in each aquarium were fed daily at the rate of $7 \%$ of their body weight; the amount was fixed after observing that it was not interested to take more than that amount of feed.

Sampling procedure: Every $10 \mathrm{~d}$, the body weight of fish were measured. For weighing 5 fingerlings were collected from each aquarium. All animals were placed on paper towels to remove excess water and then weighed using an electric balance (Mettler PJ3000). After recording the length and weight of fingerlings were released in the aquarium.

\section{Measurement of water quality parameters}

All the following water quality parameters were recorded at 10 days interval.

\begin{tabular}{|c|c|}
\hline Item & $\%$ \\
\hline Ash & 6.35 \\
\hline Nitrogen & 0.57 \\
\hline Phosphate & 1.06 \\
\hline Potassium & 2.10 \\
\hline Silicon dioxide & 1.20 \\
\hline $\mathrm{pH}$ & 8.50 \\
\hline
\end{tabular}

Table 1: Composition of $\mathrm{BC}$ powder.

\begin{tabular}{|c|c|}
\hline Item & $\%$ \\
\hline Moisture & 10 \\
\hline Protein & 28 \\
\hline Crude fat & 6 \\
\hline Ash & 18 \\
\hline Crude fiber & 7 \\
\hline Calcium & 1.8 \\
\hline Phosphorus & 0.7 \\
\hline Gross energy (Kcal/Kg) & 3400 \\
\hline
\end{tabular}

Table 2: Ingredient and chemical composition of the basal commercial diet.
Ammonia: Ammonia $\left(\mathrm{NH}_{3}-\mathrm{N}\right)$ of the aquarium water was recorded in $\mathrm{mg} / \mathrm{l}$ with the help of ammonia test kit (Hanna Instrument Ammonia Test Kit for Fresh Water).

Dissolved oxygen: Dissolved oxygen of the aquarium water was recorded in $\mathrm{mg} / 1$ with the help of a dissolved oxygen meter (Model Oxi 3150i, Germany).

$\mathrm{pH}: \mathrm{pH}$ of the water was recorded with the help of a $\mathrm{pH}$ meter $(\mathrm{pH}$ meter L20 ME 1-1 LER TOLEDO, Switzerland).

\section{Histological observation of intestine}

For the histological observation intestines were quickly removed from fish and place in $10 \%$ formaldehyde fixative solution. Then the anterior and middle central portions of the intestine of $0.5 \mathrm{~cm}$ thickness were put into the cassettes separately for histological examination. They were dehydrated in graded alcohol series, embedded in paraffin, sectioned for $5-7 \mu \mathrm{m}$ in thickness using a microtome (MICROM HM355S, Germany) and stained with Haematoxylin and Eosin, then mounted in DPX mountant and photographed with an OLYMPUSCX41 microscope which was equipped with the SONY DSC-W220 camera. At least two glass slides were prepared from each portion of the intestine.

\section{Data analysis}

The collected data were statistically analyzed by one way ANOVA (analysis of variance) with the help of SPSS (Statistical Package for Social Science) to see whether the influence of different treatments on these parameters were significant or not.

\section{Results}

\section{Water quality parameters}

Ammonia: The ammonia $\left(\mathrm{NH}_{3}-\mathrm{N}\right)$ values of water ranged from $0.02 \pm 0.01$ to $2.06 \pm 0.12 \mathrm{mg} / \mathrm{l}$ during the study period. Significantly ( $\mathrm{P}$ $<0.05$ ) higher value of ammonia which is not good for fish was found in the control while lowest value which is suitable for fish was found in $\mathrm{T}_{3}(2 \% \mathrm{BC})$ (Figure 1).

\section{pH}

The $\mathrm{pH}$ values of water ranged from $6.89 \pm 0.11$ to $7.81 \pm 0.09$ during the study period. The highest level of $\mathrm{pH}$ was found in the control while the lowest level of $\mathrm{pH}$ was found in $\mathrm{T}_{3}(2 \% \mathrm{BC})$. There were significant differences $(\mathrm{P}<0.05)$ between the control and $\mathrm{T}_{3}$. A proportional relationship between $\mathrm{pH}$ and ammonia $\left(\mathrm{NH}_{3}-\mathrm{N}\right)$ concentration were also observed during the study period (Figure 2).

\section{Dissolved oxygen}

During the study period dissolved oxygen content of water ranged from $4.58 \pm 0.32$ to $5.97 \pm 0.09 \mathrm{mg} / \mathrm{l}$. The highest value $5.97 \pm 0.09$ $\mathrm{mg} / \mathrm{l}$ was found in $\mathrm{T}_{3}$ which was significantly $(\mathrm{P}<0.05)$ higher than the control. An inverse relationship between dissolved oxygen and ammonia $\left(\mathrm{NH}_{3}-\mathrm{N}\right)$ concentration were observed during the study period (Figure 3).

\section{Growth parameters}

As shown in Table 3 the maximum growth enhancement was noticed at the $2 \% \mathrm{BC}$ supplementation level. However, fish groups that received dietary $\mathrm{BC}$ from 0.5 to $2 \%$ level showed higher values of weight gain, SGR and FCR than the control. No significant differences in final length and length gain were observed between fish fed BC containing 
Citation: Quaiyum MA, Jahan R, Jahan N, Akhter T, Sadiqul IM (2014) Effects of Bamboo Charcoal Added Feed on Reduction of Ammonia and Growth of Pangasius hypophthalmus. J Aquac Res Development 5: 269. doi:10.4172/2155-9546.1000269

Page 3 of 5

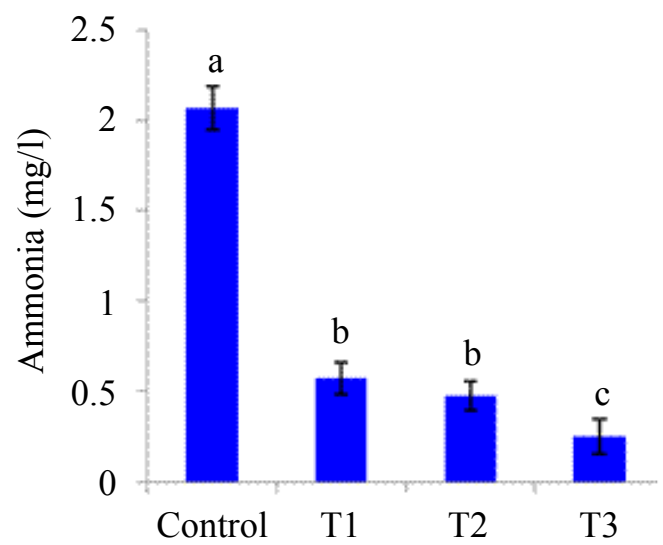

Figure 1: Ammonia $\left(\mathrm{NH}_{3}-\mathrm{N}\right)$ concentration $(\mathrm{mg} / \mathrm{l})$ in different treatments during the study period. $a, b, c$ means with different superscripts are significantly different from each other $(P<0.05)$.

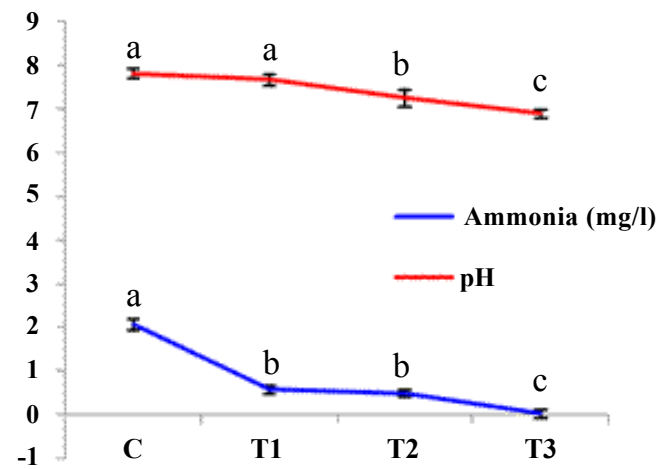

Figure 2: pHin different treatments during the study period. $a, b, c$ means with different superscripts are significantly different from each other $(P<0.05)$

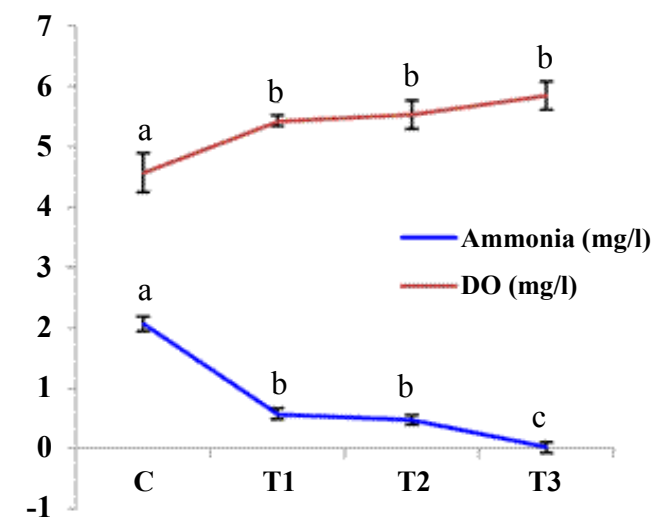

Figure 3: Dissolved oxygen $(\mathrm{mg} / \mathrm{l})$ in differenttreatments. Different superscript alphabets in each treatment group are significantly different at $\mathrm{P}<0.05$.

diet. It was also seen that the survival rates of $P$. hypophthalmus under the trail treatments were significantly $(\mathrm{P}<0.05)$ higher than the control. In an experiment in the earthen pond our study showed that $1.5 \%$ BC supplementation level was suitable for the maximum growth enhancement (data not shown) (Table 3).
Values are presented as mean \pm SE. Values in the same row having different superscript letters are significantly different $(\mathrm{P}<0.05)$. The lack of superscript letter indicates no significant differences among treatments.

Mean weight gain=mean final weight $(\mathrm{g})$-mean initial weight $(\mathrm{g})$;

Mean length gain=mean final length $(\mathrm{cm})$-mean initial length $(\mathrm{cm})$;

$\%$ Weight gain= $=($ final body weight - initial body weight $) \times 100 /$ initial body weight;

$\%$ Length gain $=($ final body length - initial body length $) \times 100 /$ initial body length;

Specific growth rate $(\mathrm{SGR})=(\log$ final body weight $-\log$ initial body weight $) \times 100 /$ feeding period;

Feed conversion ratio $(\mathrm{FCR})=$ feed fed/live weight gain;

Survival rate $(\%)=$ No. of fish harvested $\times 100 /$ No. of fish stocked.

\section{Histological observation}

Intestine of $P$. hypophthalmus of all treatments had almost normal structure but there was slight change in the villus height and lumen area of those intestines. It was observed that villus height was increased and consequently lumen areas of those intestines were decreased with increasing BC supplementation level (Figure 4).

\begin{tabular}{|l|l|l|l|l|}
\hline Parameters & Control & $\mathbf{T}_{1}$ & $\mathbf{T}_{2}$ & $\mathbf{T}_{3}$ \\
\hline Initial weight (g) & $1.17 \pm 0.40$ & $1.17 \pm 0.40$ & $1.17 \pm 0.40$ & $1.17 \pm 0.40$ \\
\hline Initial length (cm) & $3.63 \pm 0.15$ & $3.63 \pm 0.15$ & $3.63 \pm 0.15$ & $3.63 \pm 0.15$ \\
\hline Final weight (g) & $2.88 \pm 0.03^{\mathrm{c}}$ & $3.02 \pm 0.06^{\mathrm{c}}$ & $3.21 \pm 0.03^{\mathrm{b}}$ & $3.67 \pm 0.05^{\mathrm{a}}$ \\
\hline Final length (cm) & $6.36 \pm 0.29$ & $6.79 \pm 0.43$ & $6.82 \pm 0.16$ & $7.10 \pm 0.34$ \\
\hline Weight gain (g) & $1.71 \pm 0.03^{\mathrm{c}}$ & $1.85 \pm 0.06^{\mathrm{c}}$ & $2.03 \pm 0.03^{\mathrm{b}}$ & $2.50 \pm 0.05^{\mathrm{a}}$ \\
\hline Length Gain (cm) $^{2}$ & $2.73 \pm 0.29$ & $3.16 \pm 0.43$ & $3.19 \pm 0.16$ & $3.46 \pm 0.34$ \\
\hline \% Weight gain (\%) & $145.32 \pm 2.70^{\mathrm{c}}$ & $157.22 \pm 5.58^{\mathrm{c}}$ & $172.80 \pm 2.73^{\mathrm{b}}$ & $212.46 \pm 4.71^{\mathrm{a}}$ \\
\hline \% Length gain (\%) & $75.22 \pm 7.99^{\mathrm{c}}$ & $87.06 \pm 12.07^{\mathrm{b}}$ & $87.79 \pm 4.63^{\mathrm{b}}$ & $95.41 \pm 9.53^{\mathrm{a}}$ \\
\hline SGR (\% per day) & $0.73 \pm 0.01^{\mathrm{c}}$ & $0.78 \pm 0.02^{\mathrm{c}}$ & $0.84 \pm 0.01^{\mathrm{b}}$ & $0.97 \pm 0.01^{\mathrm{a}}$ \\
\hline FCR & $3.44 \pm 0.06^{\mathrm{d}}$ & $3.18 \pm 0.11^{\mathrm{c}}$ & $2.89 \pm 0.04^{\mathrm{b}}$ & $2.35 \pm 0.05^{\mathrm{a}}$ \\
\hline Survival rate (\%) & $77.33 \pm 0.88^{\mathrm{b}}$ & $84 \pm 1.15^{\mathrm{a}}$ & $82 \pm 0.57^{\mathrm{a}}$ & $84 \pm 1.15^{\mathrm{a}}$ \\
\hline
\end{tabular}

Table 3: Growth parameters of $P$. hypophthalmus.
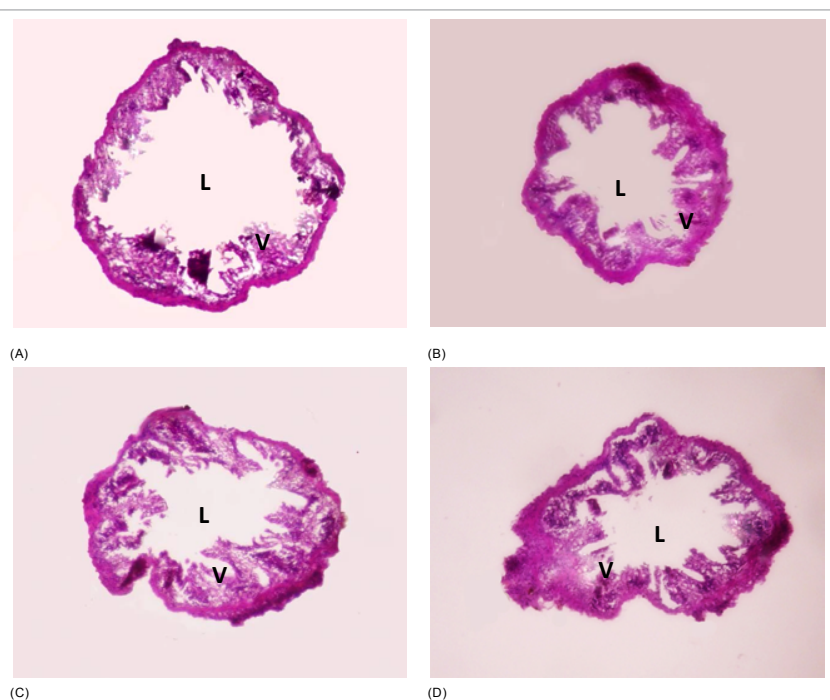

Figure 4: Histological section of the intestine of $P$. hypophthalmuscollected from the (A) control; $(B) \mathrm{T}_{1} ;(C) \mathrm{T}_{2}$; and $(D) \mathrm{T}_{3}$. (V=villus, L=lumen) 
Citation: Quaiyum MA, Jahan R, Jahan N, Akhter T, Sadiqul IM (2014) Effects of Bamboo Charcoal Added Feed on Reduction of Ammonia and Growth of Pangasius hypophthalmus. J Aquac Res Development 5: 269. doi:10.4172/2155-9546.1000269

Page 4 of 5

\section{Discussion}

\section{Water quality parameters}

One important objective of this study is to determine whether the ammonia nitrogen could be reduced by dietary BC. Some studies have reported on the ammonia nitrogen excretion of Japanese flounder (Paralichthys olivaceus) [12-15]. In the present experiment, the maximum ammonia $\left(\mathrm{NH}_{3}-\mathrm{N}\right)$ concentration was found in the control while minimum concentration was recorded at $\mathrm{T}_{3}$ and concentration increased with decreasing $\mathrm{BC}$ supplementation level. This result showed the dose-related effect of dietary $\mathrm{BC}$ on ammonia concentration.

During the study period a relationship among ammonia, $\mathrm{pH}$, and dissolved oxygen were observed. In the control, ammonia and $\mathrm{pH}$ values were high and $\mathrm{DO}$ was low. It was found that ammonia and $\mathrm{pH}$ were decreased but DO was increased with increasing $\mathrm{BC}$ supplementation level and the lowest value of ammonia was found in $\mathrm{T}_{3}$ where the higher level of BC (2\%) was supplied. These results indicated that the dietary $\mathrm{BC}$ supplementation could be a potential feed additive to eliminate the ammonia from the culture system.

\section{Growth performances}

Based on the growth data, the optimum dietary BC supplementation level for the $P$. hypophthalmus was found to be $2 \%$ of the diet. The maximum mean final weight was $3.68 \mathrm{~g}$ in $\mathrm{T}_{3}$ where higher level of $\mathrm{BC}$ was supplied. The minimum mean final weight was $2.89 \mathrm{~g}$ in the control where $0 \% \mathrm{BC}$ was supplied. Again the maximum mean final length was $7.1 \mathrm{~cm}$ observed in $\mathrm{T}_{3}$ and the minimum mean final length was $6.37 \mathrm{~cm}$ observed in the control. However, our experiment in the earthen pond indicated a little bit lower concentration of BC (about 1.5\%) than the aquarium was the optimum for the growth of $P$. hypophthalmus and elimination of ammonia (data not shown). The present finding was less than that found in study where the highest weight gain was obtained at $4 \%$ BC supplementation in tiger puffer fish [15]. Although it was found $0.5 \% \mathrm{BC}$ was suitable level for optimum growth of juvenile flounder [16]. These results indicated the species-related effect of dietary BC on growth, and it might be because of the differences in digestion and feeding behaviors of these species. In the Aigamo ducks [17] it was found that the highest mean final weight gain was in $1 \%$ SB (mixture of bamboo charcoal powder and bamboo vinegar solutions) group.

In the present experiment the mean weight gain of P. hypophthalmus in different treatments varied from 1.71 to $2.50 \mathrm{~g}$. The highest mean weight gain was found in $\mathrm{T}_{3}$ while the lowest mean weight gain was observed in the control. Again the highest mean length gain $(3.46 \mathrm{~cm})$ was found in $\mathrm{T}_{3}$ and the lowest mean weight gain $(2.73 \mathrm{~cm})$ was found in the control which is almost similar to the findings of [16]. In white leghorn hens (Gallus domesticus) the highest weight gain was observed in case of $0.5 \%$ of BC supplementation [17] whereas in Aigamo ducks the mean weight gain of $1 \% \mathrm{SB}$ group was $8 \%$ heavier than the control group [18].

The higher percent weight gain was found in $\mathrm{T}_{3}$ and it was $212.46 \%$ while the lower percent weight gain was found in the control which was $145.32 \%$. Again the higher percent length gain was $95.41 \%$ which was found in $\mathrm{T}_{3}$ and the lower percent length gain was $75.23 \%$ which was found in the control. More or less similar type of percent weight gain was observed in Japanese flounder by [16].

The specific growth rates of our studied fish under different treatments were varied from 0.73 to $0.97 \%$. SGR value was higher in $\mathrm{T}_{3}$ where $\mathrm{BC}$ level was higher (2\%) and SGR value was lower in control where fish reared without BC. SGR were observed 0.02 to $0.68 \%$ in $P$. hypophthalmus using 35-40\% protein containing feed [19]. The result obtained in our study was much lower than that (3.09 to $3.51 \%)$ was found by [20] in Thai pangas. The FCR under different treatments ranged from 2.36 to 3.44. The improved performance of FCR was observed at $2 \% \mathrm{BC}$ containing diet that is similar to the findings of $[16,18]$.

Our findings indicated that the dietary BC supplementation could be a potential feed additive to enhance the growth of $P$. hypophthalmus and supports research in tiger puffer [15] and other studies that reported growth in goats [8], in broiler chicks [21], and in Japanese flounder [22].

\section{Histological studies}

During the experiment it was observed that, intestine of $P$. hypophthalmus of all treatments had almost normal structure. The villus height and villus area of intestines of same treatment were almost in similar structure but there was a slight change in the internal configurations of intestines of different treatments. It was also observed that villus height was increased and lumen area was decreased with increasing BC supplementation level. Increased height of intestinal villi means a greater surface area for nutrient absorption [23]. Greater villus height and increased cell mitosis numbers in the intestine are indicators of activation of the function of the intestinal villi [24,25]. Furthermore, increased villus size was also associated with activated cell proliferation in the crypt [26] and provided more surface area for nutrient absorption and thus improved nutrient digestibility [23]. These reports suggest our findings that the increased villus height and decreased lumen area in $\mathrm{BC}$ supplemented fish would be multiplicatively stimulated by the influence of BC.

\section{Acknowledgment}

The authors wish to thank Bangladesh Agricultural University Research System (BAURES) for financial support to MS Islam for making it possible to carry out this research. The assistance of Professor Dr. Harunur Rashid of the Department of Fisheries Management, Bangladesh Agricultural University for the histology work is gratefully acknowledged.

\section{References}

1. Nesar A, Hasan MR (2007) Sustainable livelihoods of pangus farming in rural Bangladesh. Sustainable Aquacult 2: 5-11.

2. Ali MZ, Hossain MA, Mazid MA (2005) Effect of mixed feeding schedules with varying dietary protein levels on the growth of sutchi catfish, Pangasius hypophthalmus (Sauvage) with silver carp, Hypophthalmichthys molitrix (Valenciennes) in ponds. Aquacult Res 36: 627-634.

3. Person-Le Ruyet J, Chartois H, Quemener L (1995) Comparative acute ammonia toxicity in marine fish and plasma ammonia response. Aquacult 136 181-194.

4. Cowey CB, Cho CY (1991) Nutritional Strategies and Aquaculture Waste Proceedings of the first international symposium on nutritional strategies in management of aquaculture waste, University of Guelph, Guelph, Ontario, Canada.

5. Talbot C, Hole R (1994) Fish diets and the control of eutrophication resulting from aquaculture. J Applied Ichth 10: 258-270.

6. Zhao R, Yuan J, Jiang T, Shi J, Cheng C (2008) Application of bamboo charcoal as solid-phase extraction adsorbent for the determination of atrazine and simazine in environmental water samples by high-performance liquid chromatography-ultraviolet detector. Talanta 76: 956-959.

7. Mekbungwan A, Yamakuchi K, Sakaida T (2004) Intestinal villus histological alterations in piglets fed dietary charcoal powder including wood vinegar compound liquid. Anat Histol Embryol 33: 11-16.

8. Van DTT, Mui NT, Ledin I (2006) Effect of method of processing foliage of 
Citation: Quaiyum MA, Jahan R, Jahan N, Akhter T, Sadiqul IM (2014) Effects of Bamboo Charcoal Added Feed on Reduction of Ammonia and Growth of Pangasius hypophthalmus. J Aquac Res Development 5: 269. doi:10.4172/2155-9546.1000269

Page 5 of 5

Acacia mangium and inclusion of bamboo charcoal in the diet on performance of growing goats. Animal Feed Sci Tech 130: 242-256.

9. Prasad KSN, Aruna C, Chhabra A (2000) Effect of addition of charcoal in the concentrate mixture on rumen fermentation, nutrient utilization and blood profile in cattle. Ind J Dairy Biosci 11: 116-119.

10. Asada T, Ohkubo T, Kawata K, Oikawa K (2006) Ammonia adsorption on bamboo charcoal with acid treatment. J Health Sci 52: 585-589.

11. Yang S, Wen Y, Liu F (2009) Bamboo charcoal boosts tilapia growth Aquafeed, 29.

12. Alam MS, Teshima S, Ishikawa M, Koshio S (2002) Arginine requirement of juvenile Japanese flounder Paralichthys olivaceus. Estimated by growth and biochemical parameters. Aquacult 205: 127-140.

13. Kikuchi K, Takeda S, Honda H, Kiyono M (1991) Effect of feeding on nitrogen excretion of Japanese flounder, Paralichthys olivaceus. Nippon Suisan Gakkaishi 57: 2059-2064

14. Kikuchi K, Takeda S, Honda H, Kiyono M (1992) Nitrogen excretion of juvenile and young Japanese flounder, Paralichthys olivaceus. Nippon Suisan Gakkaishi 58: 2329-2333.

15. Moe T, Ishikawa M, Koshio S, Yokoyama S (2009) Effects of dietary bamboo charcoal on growth parameters and nutrient utilization of tiger puffer fish Takifugu rubripes. Aquacult Sci 57: 53-60.

16. Moe T, Koshio S, Ishikawa M, Yokoyama S (2010) Effects of supplementation of dietary bamboo charcoal on growth performance and body composition of juvenile Japanese flounder, paralichthys olivaceus. J World Aquacult Soc 41 : 255-262.

17. Ruttanavut J, Yamauchi K, Goto H, Erikawa T (2009) Effects of dietary bamboo charcoal powder including vinegar liquid on growth performance and histological intestinal change in aigamo ducks. Int J Poultry Sci 8: 229-236.
18. Yamauchi K, Ruttanavut I, Takenoyama S (2010) Effects of dietary bamboo charcoal powder including vinegar liquid on chicken performance and histological alterations of intestine. J Animal Feed Sci 19: 257-268.

19. Alam MS (2004) Growth performances and morphological variations among Thai pangas, $P$. hypophthalmus collected from four different hatcheries in Mymensingh. Bang J Prog Agr 15: 141-149.

20. Azimuddin KM (1998) Effect on Stocking Density on the Growth of Thai pangus, Pangasius sutchi (Folwer) in Net Cage by Using Formulated Diet, MS Thesis, Department of Aquaculture, Bangladesh Agricultural University, Mymensingh, Bangladesh.

21. Kutlu HR, Unsal L, Gorgulu M (2001) Effects of providing dietary wood (oak) charcoal to broiler chicks and laying hens. Animal Feed Sci Tech 90: 213-226.

22. Yoo JH, Ji SC, Jeong GS (2005) Effect of dietary charcoal and wood vinega mixture (CV82) on body composition of olive flounder, Paralichthys olivaceus. J World Aquacult Soc 36: 203-208.

23. Onderci M, Sahin N, Sahin K, Cikim G, Aydin A, et al. (2006) Efficacy of supplementation of alpha-amylase-producing bacterial culture on the performance, nutrient use and gut morphology of broiler chickens fed a corn-based diet. Poultry Sci 85: 505-510.

24. Langhout DJ, Schutte JB, Van leeuwen P, Wiebenga J, Tamminga S (1999) Effect of dietary high and low methyllated citrus pectin on the activity of the ileal microflora and morphology of the small intestinal wall of broiler chickens. Brit Poultry Sci 40: 340-347.

25. Yasar S, Forbes JM (1999) Performance and gastrointestinal response of broiler chicks fed on cereal grain-based foods soaked in water. Brit Poultry Sci 40: 65-67.

26. Lauronen J, Pakarinen MP, Kuusanmaki P, Savilahti E, Vento $P$, et al. (2000) Intestinal adaptation after massive proximal small bowel resection in the pig. Brit Poultry Sci 41: 416-423. 